\title{
Europejska wielokulturowość i wielojęzyczność
}

\section{European Multiculturalism and Multilingualism}

\author{
Dorota T. Szmidt, Agnieszka Mejnartowicz \\ DEPARTAMENT DE LINGÜÍSTICA GENERAL, UNIVERSITAT DE BARCELONA \\ GRAN VIA DE LES CORTS CATALANES, 585, o8007 BARCELONA \\ dszmidt@ub.edu, amejnartowicz@ub.edu
}

\begin{abstract}
The processes of economical, political and cultural integration to the European Union lead to the creation of a large area of interrelation among a large number of societies with different cultures and languages. This means that the traditional communication areas which have so far lived in some functional monolingualism will find themselves located in a unique interrelation process. One of the goals mentioned in the European Council documents is to promote the unity among the European societies and, at the same time, to preserve the current cultural and linguistical diversity. In the present paper we analyse the reasons for which it is necessary to protect the linguistical diversity and outlight the need to protect the European regional languages. We stream the importance of education in the "multiidentity" through the mutual knowledge of various languages and cultures which coexist in the European interrelation space.
\end{abstract}

\section{Wstęp}

Temat wielokulturowości i wielojęzyczności jest obecnie przedmiotem szerokiej dyskusji prowadzonej na forum kultury i polityki Unii Europejskiej. Między filologami, socjologami i socjolingwistami toczy się debata wokół metod zabezpieczenia istniejacej w Europie różnorodności języków i kultur. Dokumenty Rady Europy wyrażają zdecydowane dążenia do jedności narodów przy jednoczesnej ochronie różnorodności kultur i języków. Odnosi się to szczególnie do języków regionalnych lub mniejszościowych, które pozbawione są wsparcia instytucyjnego typowego dla języków urzędowych. Istnieje jednak sprzeczność miedzy, jak się wydaje, dużym zrozumieniem tych problemów na najwyższym szczeblu władz europejskich, a wysiłkami podejmowanymi w ich rozwiązywaniu w poszczególnych krajach. Polityka językowa w wielu krajach jest ciągle jeszcze w fazie projektów.

Wielojęzyczność i wielokulturowość, powiększająca się obecnie na skutek napływu do Europy obywateli z innych części świata, nie zawsze spotyka się z należytą akceptacją w społeczeństwach naszego kontynentu. Uzmysłowienie Europejczykom konieczności tej akceptacji, jak również konieczności ochrony własnych języków regionalnych lub mniejszościowych, które w sytuacji napływu ludności migracyjnej znajdują się $\mathrm{w}$ sytuacji zagrożenia, wydaje się dosyć niezbędne. 
Sprawy te nabierają szczególnej wagi zwłaszcza w krajach, które do tej pory egzystowały w funkcjonalnej jednojęzyczności; obywatele ich często nie rozumieją nawet konieczności dwujęzyczności, a co dopiero mówić o wielojęzyczności.

Ochrona słabszych, nieurzędowych języków ujęta została w Europejskiej Karcie Języków Regionalnych lub Mniejszościowych, przygotowanej do podpisu 5 listopada 1992 roku i wprowadzonej w życie 1-go marca 1998 roku. Języki regionalne lub mniejszościowe zostały zdefiniowane jako te języki, które są tradycyjnie używane na terytorium danego państwa przez obywateli stanowiących grupę liczebnie mniejszą od reszty ludności tego państwa, oraz różnią się od jego oficjalnego języka (nie obejmuje to ani dialektów języka oficjalnego, ani języków migrantów). Terytorium, na którym używany jest język regionalny lub mniejszościowy, oznacza obszar geograficzny, na którym dany język jest środkiem komunikowania się takiej liczby ludzi, która usprawiedliwia przyjęcie środków ochronnych i popierających, przewidzianych w Karcie. Języki te uważane są jako zagrożona część dziedzictwa kulturalnego Europy, a ich ochrona odpowiada jednocześnie uniwersalnemu prawu do używania języka regionalnego lub mniejszościowego w życiu prywatnym i publicznym. W pierwszej części Karta zawiera cele i zasady, które Strony zobowiązują się respektować i które dotyczą języków regionalnych lub mniejszościowych istniejących na ich terytorium. Do tych zasad należy respektowanie obszaru geograficznego każdego z tych języków oraz promocja i ułatwianie ich użycia w formie ustnej i pisanej w życiu prywatnym i publicznym (m. in. poprzez rozwój ich nauczania i badań nad nimi, a także ułatwianie wymiany międzynarodowej dla jezzyków, które istnieją $\mathrm{w}$ formie identycznej lub podobnej w innych państwach). W ciągu dalszym Karta zawiera serię postanowień, które powinne być wprowadzone $\mathrm{w}$ życie $\mathrm{w}$ celu ułatwienia używania języków regionalnych lub mniejszościowych w życiu publicznym. Postanowienia te odnoszą się do dziedzin takich jak: szkolnictwo, prawo, administracja, służby publiczne, środki przekazu, działalność kulturalna i społeczna, gospodarka oraz wymiana międzygraniczna. Każda Strona zobowiązuje się do wprowadzenia w życie co najmniej $35 \mathrm{z}$ wymienionych postanowień, $\mathrm{z}$ których pewna liczba należy do obowiazkowych.

Nie chodzi o ujmowanie języków państwowych i regionalnych w terminach konkurencji czy antagonizmu. Karta ma podejście interkulturalne i wielojęzyczne, tradycyjnie utrzymywane przez Radę Europy, mające na celu zacieśnienie stosunków między narodami, wzrost kooperacji europejskiej i polepszenie wzajemnego zrozumienia między poszczególnymi grupami w granicach każdego państwa. Karta nie obejmuje sytuacji nowych języków, często nieeuropejskich, pojawiających się na skutek ruchów migracyjnych na terenach krajów, które ją podpisują. W momencie kiedy kończymy niniejszy artykuł (6 lipca 2009 r.), postanowienia Karty Języków Regionalnych lub Mniejszościowych nie zostały jeszcze wprowadzone w życie w 9 z 33 krajów, które już ją podpisały ${ }^{1}$.

1 Stan na 6/7/2009: http://conventions.coe.int/Treaty/Commun/QueVoulezVous.asp?NT=148\&CM=1\&CL =FRE i http://www.bilbaoconference.org/home fr.htm [data dostępu: 6 lipca 2009] w j. polskim:

http://pl.kaszubia.com/wp-content/uploads/2008/08/europejska karta jezykow regionalnych lub mniejs zosciowych.pdf [data dostępu: 6 lipca 2009] 


\section{Dlaczego powinniśmy chronić różnorodność językową?}

Jak już wspomnieliśmy, ochrona jezyków regionalnych lub mniejszościowych nie we wszystkich społeczeństwach europejskich spotyka się $\mathrm{z}$ należytym zrozumieniem. Właśnie $\mathrm{w}$ tej chwili, $\mathrm{w}$ dobie globalizacji i tendencji do zacierania się różnic między kulturami europejskimi, dobrze jest zdać sobie sprawę z wagi problemu wobec którego stajemy. Jak już zaznaczyliśmy, Europejska Karta Języków Regionalnych lub Mniejszościowych jest wyrazem zrozumienia tych problemów na najwyższym szczeblu władz europejskich, jednakże wystarczy analiza tendencji politycznych $\mathrm{w}$ niektórych krajach europejskich, aby się przekonać, że problem nie został dostatecznie zrozumiany. Wiąże się to przede wszystkim z tym, że elektorat w tych krajach nie jest jeszcze przygotowany na to, by zrozumieć konieczność wielojęzyczności i wielokulturowości. Przeważnie nie podważa się faktu, iż języki regionalne stanowią dziedzictwo narodowe, które należy chronić. Ciekawe jednak, że kiedy zaczyna się szukać sposobów ochrony wyłania się to, iż właściwie chodzi o ich ochronę niemal jedynie na poziomie folklorystycznym. Sytuacja języków regionalnych, które używane są wyłącznie na własnym obszarze i nie istnieje żadne państwo, które posługiwałoby się nim jako językiem urzedowym, jest szczególnie delikatna. Jak już wspomnieliśmy, w większości społeczeństw europejskich na ogół nie jest dostatecznie zrozumiana potrzeba polityki skierowanej na wzmacnianie pozycji języków regionalnych na ich własnym terytorium. Tego rodzaju przedsięwzięcia przyjmowane są nawet jako zagrażające jedności państwa i rodzą animozje w stosunku do ludności tych regionów. Socjolingwiści ostrzegają, że języki regionalne pozbawione wsparcia instytucyjnego, są o wiele słabsze w kontakcie z językiem urzędowym państwa, na którego terenie funkcjonują. Przewaga języka urzędowego wynika z jego wyższej używalności, poprzez większą liczbę kontekstów komunikacyjnych, a także większą liczebność jego użytkowników. W tej sytuacji może dojść nawet do całkowitego wymarcia języków regionalnych, wypieranych stopniowo przez język urzędowy państwa. Proces ten $\mathrm{w}$ wielu krajach rodzi konflikty. $\mathrm{Z}$ punktu widzenia socjolingwistyki, konflikt lingwistyczny w regionach o własnym języku znacznie się zmniejsza, gdy członkowie różnych grup językowych odczuwają jednakową presję poznawania kodu językowego drugiej grupy. I tak grupa autochtoniczna nabywa znajomość języka o użyteczności supralokalnej, a grupa alochtoniczna jezzyka lokalnego, użytecznego w funkcjach życia codziennego (Bastardas, 1996). Sytuacja europejskich języków regionalnych powinna więc być szeroko omówiona, zrozumiana i, co za tym iść powinno, rozwiązana w świetle woli ich ochrony.

Wydaje się więc sensownym przypomnienie argumentów na uzasadnienie ochrony różnorodności językowej. Argumenty te są wielostopniowe. Mają one wymiar jednostkowy, społeczny i gatunkowy. Odnośnie wymiarów jednostkowego i społecznego chodzi oczywiście o wygodę egzystowania we własnej kulturze lokalnej, która wyraża się w języku. Wiadomo, że fakt ten ma konsekwencje nawet ekonomiczne, gdyż daje danej społeczności poczucie jedności i wiarę w siebie, które pozytywnie wpływają na jej żywotność.

Wymiar gatunku dostarcza nam argumentu niejako podstawowego dla ochrony języków. Istnieje paralelizm między ekologią biologiczną a ekologią lingwistyczną. Idea ta, wyrażona między innymi przez takich lingwistów jak Haugen (1971), Mackey (1979), Lieberson (1981), Ivanov (1992), Bastardas (1996) czy Crystal (2001), głosi iż języki, tak jak organizmy biologiczne, muszą utrzymywać się w 
stanie żywym. Jak wiemy, w świecie organizmów biologicznych, różnorodność jest w prostej korelacji ze stabilnością, ekosystemy najsilniejsze i najbardziej dynamiczne są jednocześnie najbardziej różnorodne. W antropologii zaznacza się, że powodzenie naszego gatunku $\mathrm{w}$ kolonizacji planety zasadza się na naszej umiejętności tworzenia różnorodnych kultur zdolnych do adaptowania się $\mathrm{w}$ różnych warunkach środowiskowych. Jeżeli rozwój różnorodnych kultur ma taka wagę, rola języka jest tu podstawowa, gdyż jest nie tylko jej nośnikiem, ale jednocześnie pryzmatem przez który świat odbieramy. Cytując Ivanova (1992): „Każdy język jest pewnym modelem, semiotycznym systemem rozumienia świata. Mając 4.000 różnych sposobów opisu świata jesteśmy bogaci. Powinniśmy zająć się ochroną języków tak jak zajmujemy się ochroną organizmów biologicznych". W języku znajduje również wyraz nasza historia. Poprzez słowa i wyrażenia których używamy, język utrzymuje ślady sposobu myślenia naszych przodków, a także ich różnorodnych kontaktów kulturowych. Każdy język posiada setki tysięcy słów i wyrażeń, a także konstrukcji gramatycznych stworzonych po to aby nimi operować. Potencjał dla interakcji, nawet między tylko dwoma językami, jest olbrzymi. I jak mówi Pogson (1998): "Różnorodność językowa jest podstawą rozkwitu naszego gatunku. Jest jak pożywka bulionowa... Abyśmy mogli prosperować, potrzebujemy wzajemnej fertylizacji intelektualnej, której dostarcza nam wielojęzyczność”.

\section{Polskie doświadczenia zwiazane $\mathrm{z}$ wielojęzycznością $\mathrm{i}$ wielokulturowością.}

Procesy integracyjne, nie tylko ekonomiczne, ale również polityczne i kulturowe, które rozpoczęły się w Unii Europejskiej prowadzą do utworzenia jednej wielkiej przestrzeni interakcyjnej. W przestrzeni tej będą zanurzone obszary, które do tej pory egzystowały w pewnej funkcjonalnej jednojęzyczności. Przyszłość ta otwiera perspektywy, które nam, badaczom historii narodów słowiańskich, przypomina z jednej strony czasy Rzeczpospolitej Obojga Narodów, z drugiej strony niesławną epokę opancerzonych granic nie tak oddalonej w czasie rzeczywistości sowieckiej. Te dwa okresy w historii narodów, z których niektóre już weszły do Unii Europejskiej, dostarczają pewnych elementów do refleksjii na temat tego jak różnorodność językowa i kulturowa powinna być potraktowana $\mathrm{w}$ tej nowej przestrzeni interakcyjnej.

Przypomnijmy najpierw Rzeczpospolitą Obojga Narodów, utworzoną w 1569 roku i obejmującą na swych wschodnich terenach liczne narody, przede wszystkim Polaków, Litwinów, Ukraińców, Biełorusinów, Żydów, Niemców, nie mówiąc już o mniejszych grupach narodowych takich jak Ormianie czy Tatarzy. Pomimo napięć politycznych, szczególnie poczynając od wieku XIX kiedy w całej Europie zaczęly się krystalizować idee narodowościowe, w pamięci pisarzy i myślicieli poskich Kresy, ziemie graniczne, pozostawiły wspomnienie mitycznej Arkadii, przebogatej kulturalnie i stymulującej. Nie musimy wymieniać nazwisk $\mathrm{z}$ długiej listy znakomitych twórców, których wydały te wielojęzyczne i wielokulturowe terytoria. A jednak mit kresowej Arkadii nie jest podstawowym elementem dziedzictwa symbolicznego polskiej kultury tych terenów. Jest nim przede wszystkim to, co Lech Witkowski nazywa „efektem pogranicza”, bardzo ważnym i płodnym intelektualnie, który z jednej strony „chroni przed fanatyzmem i ksenofobią, a z drugiej strony, przed kosmopolityzmem pozbawionym korzeni i przed niemożnością życia w sposób twórczy w diasporze emigracyjnej” (Witkowski 1998).

Wg. Witkowkiego, koniecznym warunkiem tego by obszary symbiozy 
przygranicznej mogły działać jako bufor pozwalający na płynne przejście z jednej kultury w drugą, dodając nowej jakości kulturalnej, jest pewien „symboliczny katalizator międzygrupowy”, wspólny mit, który chroni przed nieufnością wobec sąsiada, z którym dzieli się terytorium. Nie wszystkie terytoria przygraniczne go wytwarzają. Może mogłaby to być swego rodzaju mentalność „interkulturalna” wielu z mieszkańców Kresów, Polaków patriotów, a jednocześnie dumnych z bogactwa kulturalnego rodziny do której mogli należeć dziadkowie Litwini, wujowie Niemcy, czy Białorusini? Wielu z tych Polaków urodzonych na Kresach zachowało znajomość języków, które poznali w dzieciństwie. Często już ich alfabetyzacja była wielojęzyczna.

Przyjrzyjmy się teraz epoce zimnej wojny. Istnienie granic nie jest gwarancją istnienia terenów pogranicza. Są granice, które uniemożliwiają lub reglamentują możliwości kontaktu z innością. Przykładem na to może być tzw. „mur wstydu”, który do nie tak dawna oddzielał „Wschód” od „Zachodu” Europy. Byliśmy również świadkami tego jak narody połączone wcześniej przeciw własnej woli pod wspólną flagą zapragneły odzyskania i potwierdzenia swej tożsamości. Widzimy jednak, że po okresie przejściowym te same narody są już otwarte na nowe, dobrowolne zrzeszenia.

Doświadczenie Kresów wskazuje na to, iż współżycie wielojęzyczne i wielokulturowe jest nie tylko możliwe lecz, z punktu widzenia dostarczania społeczeństwu intelektualnych bodżców, jak najbardziej pożądane. Niedaleka jeszcze wojenna przeszłość niektórych krajów bloku sowieckiego doradza rozwagę polityczną w traktowaniu kultur regionalnych. Ich sytuacja w obecnej integracyjnej Europie staje się jeszcze bardziej złożona. Masowy napływ ludności spoza Europy komplikuje ją dodatkowo. Może on oznaczać dla ludności miejscowej posługującej się językiem regionalnym utratę równowagi w organizacji socjolingwistycznej, która była utrzymywana do tego momentu, szczególnie gdy ludność przemieszczająca się na jej obszar odczuwa większą przydatność używania języka „państwowego” i proporcje demograficzne zaczynają być znacznie korzystniejsze dla grupy posługującej się nim. W wyniku zachwiania tej równowagi może dochodzić do konfliktów. Nie zapominajmy o tym, że aby przyjąć „innego” z jego językiem i kulturą, człowiek musi mieć poczucie, że jego własny język i kultura cieszą się dobrym zdrowiem. Owo „dobre zdrowie” w przypadku języków regionalnych może być utrzymane poprzez uznanie jego pierszeństwa $\mathrm{w}$ regionie wobec języka państwowego, co pozwala na utrzymywanie funkcji, które wskazują na jego użyteczność. Dla grupy etnicznej mniejszościowej własny język jest oznaką tożsamości o wartości emocjonalnej. Socjolingwistyka dostarcza danych, które świadczą o tym, iż języki regionalne b€dące aktualnie w recesji pójdą dalej drogą kulturalnego zanikania jeżeli nie zostaną wprowadzone poważne zmiany $\mathrm{w}$ organizacji społecznej na ich własnym terenie. Droga sporadycznego wsparcia finansowego może pomóc w ich utrzymaniu na poziomie kulturalnofolklorystycznym, ale nie sprzyja ich rozwojowi. Jedyne co może prowadzić do ich utrzymania i normalnego rozwoju jest przywrócenie utraconych funkcji życia codziennego i społecznego. Aby skutecznie chronić różnorodność językową, ułatwiać integrację nowoprzybyłych i zapewnić pełną interkomunikację między mieszkańcami danego regionu, wysunięta została propozycja zastosowania zasady subsydiarności na polu komunikacji językowej. Termin ten, przeniesiony z terenu polityczno-administracyjnego na teren glotopolityki oznaczałby, że „wszystko to co może być zrobione w języku lokalnym, nie powinno być robione w języku bardziej globalnym" (Bastardas, 2002:5). Zasada ta może być stosowana na wszystkich 
poziomach kontaktów między językami, zarówno między językami regionalnymi i urzędowymi wewnątrz państwa, jak i między językami urzędowymi małych państw i językami interkomunikacji.

\section{Ochrona różnorodności językowej a tendencje centralistyczne.}

W świetle tych faktów, wydaje się dosyć rozsądnym pomyśleć o wielojęzycznym nauczaniu w szkołach. Niektóre kraje będą musiały dokonać pewnego wysiłku i zmienić swe tendencje centralistyczne. Jednym z nich jest niewątpliwie Francja. Kraj ten systematycznie odmawiał uznania wielojęzyczności wewnatrz swych granic i od czasów Rewolucji Francuskiej stosował zasadę centralizacji językowej. Dopiero od 1997 roku polityka językowa Francji stała się bardziej tolerancyjna. W maju 1999 roku Francja podpisała Europejską Kartę Języków Regionalnych lub Mniejszościowych. Uczyniła to pod presją Rady Europy, ale do tej pory, a więc do momentu zakończenia niniejszego artykulu, kraj ten nie ma konkretnej daty wprowadzenia postanowień Karty w życie. Sytuacja języków w Wielkiej Brytanii nie była o wiele lepsza. Wielka Brytania podpisała Kartę Języków w 1998 roku. Od tego czasu jednak, w dziedzinie językowej miało miejsce $\mathrm{w}$ tym kraju wiele wydarzeń pozytywnych jak na przykład wprowadzenie języka walijskiego do szkół czy utworzenie Zgromadzenia Narodowego Walii, które zajmuje się ochroną i promocją języka walijskiego. Do rozszerzonej obecnie do 27 krajów Unii Europejskiej nowe kraje członkowskie wprowadziły swoje własne języki państwowe uznane jako oficjalne, ale również i języki regionalne. Jednym z tych krajów jest Polska, która podpisała Kartę w roku 2003 i ratyfikowała 1-go czerwca 2009 roku, a więc może już wprowadzić jej postanowienia w życie.

Nie jest łatwo przekonać rządy poszczególnych krajów, głównie tych wielonarodowościowych o tradycjach centralistycznych, że dwujęzyczność jest nie tylko konieczna, ale i korzystna. To, iż państwa wielonarodowościowe identyfikuje się $\mathrm{z}$ jednym tylko narodem etniczno-językowym wchodzącym w ich skład, jest źródłem potencjalnych konfliktów, długotrwałych, a w niektórych krajach bardzo nasilonych. O wiele korzystniejsze byłoby uznanie wielonarodowościowego charakteru tego kraju. Poczucie podwójnej, potrójnej czy poczwórnej tożsamości jest czymś zupełnie naturalnym. Tak jak czujemy się przynależni do grupy rodzinnej, czujemy się jednocześnie przynależni do grupy etnicznej, narodowej, do państwa, a także do struktury nadrzędnej jeszcze jak na przykład Unia Europejska. Takie poczucie „wieloprzynależności” występuje coraz częściej biorąc pod uwagę nakładanie się przestrzeni organizacyjnych i identyfikacyjnych. Przykładem takiego poczucia „wieloprzynależności” może być to, które posiadają mieszkańcy hiszpańskiej Katalonii, która jest Regionem Autonomicznym (po katalońsku: Comunitat Autònoma) z własnym rządem oraz dwoma językami urzędowymi: katalońskim i hiszpańskim. Katalończycy czują się również Hiszpanami (Hiszpania jest dla nich „państwem” i język hiszpański językiem „państwowym”), a przy tym są przekonanymi obywatelami Unii Europejskiej. Język kataloński jest dla nich jedną z najważniejszych wartości. To, że obecnie używany jest jako język podstawowy w szkolnictwie w Katalonii pozwala na niejakie zrównoważenie silnych wpływów języka hiszpańskiego będącego nie tylko językiem "państwowym”, ale i „międzynarodowym”. 


\section{Różnorodność językowa w społeczeństwie informacyjnym.}

Obecnie w dokumentach europejskich podkreśla się wagę utrzymania różnorodności językowej w społeczeństwie informacyjnym ${ }^{2}$. Przyjmuje się jako pewnik konieczność równego dostępu do informacji, która powinna być wprowadzona we własnym języku każdego obywatela Unii. Przewiduje się popieranie i wspomaganie rozwoju i użycia inżynierii lingwistycznej poprzez utworzenie europejskiej infrastruktury wielojęzycznych zasobów językowych. Celem tego przedsięwziecia jest udoskonalenie dostępu do informacji, do serwisu tłumaczeń oraz do nowych metod nauczania języków obcych. Wypada żywić nadzieję, że technologia lingwistyczna będzie nam mogła dostarczyć niebawem nowych narzędzi, które usprawnią i przyśpieszą interkomunikację. Lecz zanim na rynku nie pojawią się aparaty, które pozwolą na utrzymanie płynnej konwersacji z rozmówcą używajacym innego, nieznanego nam języka (jest to wizja futurystyczna aczkolwiek możliwa), powinniśmy zadecydować jakie języki i na których etapach nauczania powinniśmy wprowadzać do programów szkolnych.

$\mathrm{Na}$ razie $\mathrm{w}$ materii językowej przewiduje się promocję języków interkomunikacyjnych i ochronę różnorodności językowej. W tej chwili mamy parę języków interkomunikacyjnych (nie wydaje się więc, aby wielkie kraje takie jak Francja i Niemcy czuły rzeczywiste zagrożenie wobec własnych języków, tylko to bowiem skłoniłoby je do uznania potrzeby wprowadzenia jednego języka interkomunikacyjnego ekstra narodowego jakim mogłoby być na przykład esperanto, od dawna już czekające nieśmiało na swoją szansę), pokaźną liczbę innych języków państwowych oraz języki regionalne lub mniejszościowe. Miejmy nadzieję, że wyrażona wola upowszechniania nauki języków, a więc promocja wielojęzyczności w Europie będzie potwierdzona wsparciem finansowym. Powinno ono objąć nie tylko technologie językowe, ale także nauczanie języków w szkołach. Nie ulega bowiem wątpliwości, że $\mathrm{w}$ zaistniałej sytuacji konieczna będzie alfabetyzacja wielojęzyczna. W wersji „szerokiej”, a więc dotyczącej regionów z językiem lokalnym lub mniejszościowym, oprócz tego języka, priorytetowego $\mathrm{w}$ danym regionie, nauczany powinien być język „państwowy” oraz jeden lub dwa języki interkomunikacyjne (autonomiczny region Katalonii może być przykładem wprowadzania do szkoł dwóch języków: katalońskiego i hiszpańskiego już w wieku przedszkolnym, a następnie w wieku nieco późniejszym jednego języka interkomunikacyjnego, przeważnie angielskiego, a w niektórych szkołach i dwóch). W przypadku rodzin imigrantów, może tu dojść również język rodziców lub jednego z nich.

Powracając do sytuacji pogranicza, o której mówi Lech Witkowski, będzie ona charakterystyczna dla wszystkich dużych miast Europy, a już obecnie i od dość dawna, panuje w miastach takich jak Londyn, Paryż czy Berlin. Przede wszystkim tam spotykają się różnorodne kultury i języki. Zjawisko to będzie się nasilać. Obecnie już przewidziany jest $\mathrm{w}$ obrębie Unii dodatkowy wzrost wymiany obywateli, zarówno młodzieży studenckiej jak i osób pracujacych. Buforem

\footnotetext{
2 "Wieloletni program promocji różnorodności językowej w ramach Wspólnoty w społeczeństwie informacyjnym" (96/664/CE. DOCE NrL 306/40, 28-11-96).

http://eur-lex.europa.eu/LexUriServ/LexUriServ.do?uri=DD:13:26:32001Do048:PL:PDF [data dostepu: 6/07/2009]
} 
amortyzującym zderzenia, o którym pisze Lech Witkowski (1996), powinno więc być takie nastawienie, które pozwoli nam żyć spokojnie we własnej kulturze akceptując jednocześnie kultury innych. Niewątpliwie bazą do wyrobienia takiej postawy jest wzajemna ciekawość i poznanie. Jedną z dróg, które umożliwiają to poznanie jest na pewno wielojęzyczna edukacja, a przez nią i zbliżenie kulturowe. Czy nie to właśnie jest warunkiem koniecznym dla spojenia kultur wewnątrz Unii i jednoczesnej ochrony jej wielojęzyczności i wielokulturowości? 


\section{Bibliografia}

Bastardas i Boada, A. (1996): Ecologia de les llengües. Edicions Proa, Barcelona.

Bastardas i Boada, A. (2002): Política lingüística mundial a l'era de la globalització: diversitat i intercomunicació des de la perspectiva de la "complexitat" (versja angielska: World Lanuage Policy in the Era pf Globalization. Diversity and Intercommunication from the Perspectiva of "Complexity. Noves SL. Summer 2002.

Crystal, D. (2001): La muerte de las lenguas, Cambridge University Press, Madrid.

Haugen, E. (1971): The ecology of language. Linguistic Reporter, Suplement 25, vol 13, nr 1.

Ivanov, V. (1992): Reconstructing the past, Intercom 15.

European Charter for Regional or Minority Languages. Charte europénne des langues régionales ou minoritaires. 1992. Strasbourg: Council of Europe. http://conventions.coe.int/Treaty/Commun/QueVoulezVous.asp?NT=148\&CM=1\&CL =FRE [data dostępu: 6/07/2009]

http://www.bilbaoconference.org/home_fr.htm [data dostępu: 6/o7/2009]

http://pl.kaszubia.com/wp-content/uploads/2008/o8/europejska karta jezykow regio nalnych lub mniejszosciowych.pdf [data dostępu: 6/07/2009]

European Comission Multilingualism, 17 april 2008,

http://ec.europa.eu/education/languages/at-a-glance/doc1458_en.htm [data dostępu: 6/07/2009]

Lieberson, S. (1981): Language Diversity and Language Contact (Wybór: Anwar S. Dil). Stanford, Cal.: Stanford University Press.

Mackey, W.F. (1979): Sociolinguistic Studies in Language Contact. La Haia: Mouton.

Pogson, G. (1998): Digital tecnology will save your language, Info NT 2 Konferencja Serwisu Tłumaczeń Państw Europejskich, Haga, 1-5.

Witkowski, L. (1996): Bogactwo Kresów - Między pograniczem kultury a kulturą pogranicza, w Kresy w literaturze. Twórcy dwudziestowieczni. Wiedza Powszechna, Warszawa, 75-103

http://eur-ex.europa.eu/smartapi/cgi/sga doc?smartapi!celexplus!prod!CELEXnumdoc\&numdoc=32001Do 048\&lg=p l[data dostepu: 6/07/2009]

http://eur-lex.europa.eu/LexUriServ/LexUriServ.do?uri=DD:13:26:32001Do048:PL:PDF [data dostepu: 6/07/2009]: "Wieloletni program promocji różnorodności językowej w ramach Wspólnoty w społeczeństwie informacyjnym” (96/664/CE. DOCE NrL 306/40, 28-11-96). 